\title{
Additional disinfectants effective against the amphibian chytrid fungus Batrachochytrium dendrobatidis
}

\author{
R. Webb*, D. Mendez, L. Berger, R. Speare \\ Amphibian Disease Ecology Group, School of Public Health, Tropical Medicine and Rehabilitation Sciences, \\ James Cook University, Townsville 4811, Australia
}

\begin{abstract}
Chytridiomycosis, a disease contributing to amphibian declines worldwide, is caused by the fungus Batrachochytrium dendrobatidis. Identifying efficient and practical disinfectants effective against $B$. dendrobatidis is important to reduce the spread of the disease both in the wild and captivity. Previous studies identified a range of suitable disinfectant strategies. We evaluated the suitability of 3 additional disinfectants: two of these (TriGene Virucidal Disinfectant Cleaner and F10 Super Concentrate Disinfectant) are mixtures of chemicals and one (Betadine Antiseptic Liquid) contains a single active ingredient, povidone iodine. The disinfectants were tested using a range of concentrations for 1,5 and $10 \mathrm{~min}$ to determine their ability to kill $B$. dendrobatidis in vitro. The measure of effectiveness was $100 \%$ kill of zoosporangia grown in multiwell plates. All disinfectants had a $100 \%$ efficacy at concentrations recommended by the manufacturers. The lowest concentrations capable of $100 \%$ kill after exposure for $1 \mathrm{~min}$ were $0.1 \mathrm{ml} \mathrm{l}^{-1}$ for TriGene, $0.33 \mathrm{ml} \mathrm{l}^{-1}$ for F10 and $100 \mathrm{ml} \mathrm{l}^{-1}$ for Betadine. TriGene is the most effective disinfectant yet to be found, and both TriGene and F10 are more effective than various disinfectants tested in previous studies. TriGene and F10 are considered suitable for use in the field, as only small amounts of concentrate are needed.
\end{abstract}

KEY WORDS: Batrachochytrium dendrobatidis $\cdot$ Disinfect $\cdot$ TriGene $\cdot$ F10 $\cdot$ Betadine $\cdot$ Amphibian disease

Resale or republication not permitted without written consent of the publisher

\section{INTRODUCTION}

The amphibian chytrid fungus Batrachochytrium dendrobatidis is the cause of chytridiomycosis, a disease responsible for declines of amphibian populations in Australia, New Zealand, North America, Central America, South America and Europe (Berger et al. 1998, Mutschmann et al. 2000, Bosch et al. 2001, Fellers et al. 2001, Waldman et al. 2001, Bonaccorso et al. 2003, Burrowes et al. 2004, Lips et al. 2006, Puschendorf et al. 2006). Protocols to prevent the spread of chytridiomycosis by human activities include disinfection of equipment used with amphibians or that has had contact with contaminated water bodies (Australian Government Department of Environment and Heritage 2006). Disinfectants effective against $B$. dendrobatidis are also used in laboratories and in captive amphibian facilities. Johnson et al. (2003) investigated the efficacy of 8 disinfectants against $B$. dendrobatidis, and showed acceptable levels of activity for 4 , with those containing didecyl dimethyl ammonium chloride (DDAC) being active at the lowest concentration $\left(1 \mathrm{ml} \mathrm{l}^{-1}\right)$. The most commonly used disinfectant appears to be bleach at concentrations of between 1 and $4 \%$ (approximately 0.45 to $1.8 \mathrm{~g}$ sodium hypochlorite $\mathrm{l}^{-1}$ ), a much higher range of concentrations than for DDAC products. In the field, researchers often need to transport disinfectants to distant sites, and, consequently, volume and weight are important considerations. Disinfectant stock solutions can be diluted to the desired concentration with stream or pond water, and the more active a disinfectant is, the smaller the required volume of stock solution. 
F10 Super Concentrate Disinfectant (Health and Hygiene Pty.) is a wide-spectrum disinfectant designed for use in the presence of animals. It is used in zoological parks as well as veterinary and agricultural situations ${ }^{1}$. F10 contains $54 \mathrm{~g}$ benzalkonium chloride $\mathrm{l}^{-1}$ and $4 \mathrm{~g}$ polyhexamethylene biguanide hydrochloride $\mathrm{l}^{-1}$. TriGene Virucidal Surface Disinfectant Cleaner (Medichem International Marketing) is recommended for disinfecting hard surfaces and instruments. The active ingredients of the product are: dodecylamine sulphamate, octyldecyl dimethyl ammonium chloride, poly (hexamethylene) biguanide hydrochloride, 4 nonyl phenyl- $\omega$-hydroxyl-poly (oxythylene) and ethanol ${ }^{2}$. Betadine Antiseptic Liquid (Faulding Healthcare Pty.) is a commonly used topical antiseptic. The disinfectant contains $10 \%$ povidone-iodine, which is equivalent to $1 \%$ available iodine (Anonymous 1998).

The present paper reports the efficacy of these 3 disinfectants in killing Batrachochytrium dendrobatidis in vitro.

\section{MATERIALS AND METHODS}

The experiment followed Protocol 2 of Johnson et al. (2003), except for minor modifications as given in the following description. Two Batrachochytrium dendrobatidis strains were used, one isolated from Litoria caerulea (Rockhampton-Lcaerulea-99-LB-1) and another from L. rheocola (Mt Misery-Lrheocola-05-LB-1) (Berger et al. 2005b), depending on which strain was producing the most zoospores at the time. Zoospores were placed in 96-well plates to ensure that all wells contained cultures of approximately the same age. Zoospores were collected from the cultures by 2 methods. Either an agar plate supporting an active culture was flooded with tryptone, gelatin hydrolysate, lactose (TGhL) broth, left for $30 \mathrm{~min}$ and then the broth collected, or a $4 \mathrm{~d}$ old culture in TGhL broth was centrifuged at $2000 \mathrm{rpm}(690 \times g)$ for $2 \mathrm{~min}$ and the supernatant was collected. The resulting zoospore/broth solution was then diluted with broth until the zoospore concentration was $4 \times 10^{5}$ zoospores $\mathrm{ml}^{-1}$, as determined by a haemocytometer count, placed in wells and grown for 4 to $6 \mathrm{~d}$ at $21^{\circ} \mathrm{C}$. The 3 disinfectants, TriGene, F10 and Betadine, were diluted with sterile water. Sterile water was placed in the control wells. All were tested against plates containing $B$. dendrobatidis cultures of 4 to $6 \mathrm{~d}$ of age, with exposure times of 10,5 and $1 \mathrm{~min}$. Concentrations recommended by the manufacturer were used as the starting point, and the disinfectants were diluted until $B$. dendrobatidis zoospo-

${ }^{1}$ www.healthandhygiene.net/index.php?mainid=1. Accessed 15 January 2007 rangia survived. For each concentration 8 replicates were done. Plates were checked every 3 to $4 \mathrm{~d}$ for at least $2 \mathrm{wk}$ to detect growth of sporangia and presence of motile zoospores. From each inactive well containing intact zoosporangia, $20 \mu \mathrm{l}$ was transferred to fresh media after $2 \mathrm{wk}$ instead of after $4 \mathrm{wk}$ as in the original protocol of Johnson et al. (2003), since wells which were inactive for $2 \mathrm{wk}$ did not show growth after this time. For a treatment to be considered effective, it had to result in $100 \%$ kill of all 8 replicates. If liquid was transferred from these wells to fresh broth, then the additional wells had to have been inactive for the treatment to be considered effective.

\section{RESULTS}

All 3 disinfectants had $100 \%$ killing effect on zoosporangia at concentrations recommended by the manufacturers (Table 1). Betadine was only effective at much higher concentrations $\left(100 \mathrm{ml} \mathrm{l}^{-1}\right)$ of stock solution than the other 2 disinfectants. F10 and TriGene were effective at $0.33 \mathrm{ml} \mathrm{l}^{-1}(1: 3000)$ and $0.1 \mathrm{ml} \mathrm{l}^{-1}(1: 10000)$, respectively. At the lowest concentration longer exposure times changed efficacy for F10, which was only effective at $0.28 \mathrm{ml} \mathrm{l}^{-1}$ if exposure was for at least $10 \mathrm{~min}$.

Table 1. Killing effect of 3 disinfectants on Batrachochytrium dendrobatidis zoosporangia in vitro

\begin{tabular}{lcl} 
Disinfectant concentration & $\begin{array}{c}\text { Exposure } \\
\text { time (min) }\end{array}$ & 100\% effective? \\
\hline F10 & $1,5,10$ & Yes \\
$4 \mathrm{ml} \mathrm{l}^{-1}(1: 250)$ & $1,5,10$ & Yes \\
$1 \mathrm{ml} \mathrm{l}^{-1}(1: 1000)$ & $1,5,10$ & Yes \\
$0.33 \mathrm{ml} \mathrm{l}^{-1}(1: 3000)$ & 10 & Yes \\
$0.28 \mathrm{ml} \mathrm{l}^{-1}(1: 3500)$ & 1,5 & No \\
$0.28 \mathrm{ml} \mathrm{l}^{-1}(1: 3500)$ & $1,5,10$ & No \\
$0.25 \mathrm{ml} \mathrm{l}^{-1}(1: 4000)$ & & \\
Betadine & $1,5,10^{\mathrm{a}}$ & Yes \\
Full strength $^{\mathrm{a}}$ & $1,5,10^{\mathrm{a}}$ & Yes \\
$500 \mathrm{ml} \mathrm{l}^{-1} \mathrm{~b}$ & $1,5,10^{\mathrm{b}}$ & Yes \\
$100 \mathrm{ml} \mathrm{l}^{-1 \mathrm{c}}$ & $1,5,10^{\mathrm{c}}$ & No \\
$50 \mathrm{ml} \mathrm{l}^{-1} \mathrm{~d}$ & & \\
TriGene & $1,5,10$ & Yes \\
$50 \mathrm{ml} \mathrm{l}^{-1}(1: 20)$ & $1,5,10$ & Yes \\
$2 \mathrm{ml} \mathrm{l}^{-1}(1: 500)$ & $1,5,10$ & Yes \\
$1 \mathrm{ml} \mathrm{l}^{-1}(1: 1000)$ & $1,5,10$ & Yes \\
$0.2 \mathrm{ml} \mathrm{l}^{-1}(1: 5000)$ & $1,5,10$ & Yes \\
$0.1 \mathrm{ml} \mathrm{l}^{-1}(1: 10000)$ & $1,5,10$ & No \\
$0.09 \mathrm{ml} \mathrm{l}^{-1}(1: 11000)$ & & \\
& &
\end{tabular}

${ }^{2}$ www.medichem.co.uk/trigene-dis-safety.html. Accessed 28 March 2006 


\section{DISCUSSION}

The commercially available disinfectants F10, Betadine and TriGene were effective disinfectants for Batrachochytrium dendrobatidis when used for $1 \mathrm{~min}$ at the concentrations recommended by the manufacturers. The 3 products tested can be considered disinfectants where $B$. dendrobatidis may be present. Of the 3 disinfectants, TriGene was active at the lowest concentration, being effective at a dilution of $0.1 \mathrm{ml} \mathrm{l}^{-1}$, followed by F10 at a dilution of $0.33 \mathrm{ml} \mathrm{l}^{-1}$ and then Betadine at a dilution of $100 \mathrm{ml} \mathrm{l}^{-1}$. It is recommended that either TriGene or F10 be used as a disinfectant in situations where $B$. dendrobatidis may be present. The concentration of F10 recommended by the manufacturers for the disinfection of fungi, in general, is $2 \mathrm{ml} \mathrm{l}^{-1}$ for $15 \mathrm{~min}$, or, in the case of fungal spores, $4 \mathrm{ml} \mathrm{l}^{-1}$ for $30 \mathrm{~min}^{\mathbf{1}}$. For TriGene, a concentration of $10 \mathrm{ml} \mathrm{l}^{-1}$ is recommended for general cleaning, and $20 \mathrm{ml} \mathrm{l}^{-1}$ if organic material is present ${ }^{2}$. However, this study demonstrates that much lower concentrations and exposure times of both these chemicals are sufficient to kill $B$. dendrobatidis in vitro. Since organic material such as that in soil may interfere with, and reduce, the efficiency of these disinfectants (Wilson \& Margolin 2003), higher concentrations should be used in the

Table 2. Disinfectant options for the amphibian chytrid for various purposes in amphibian research and husbandry. Apart from the data on F10 and TriGene from this study, all data are based on Johnson et al. (2003). DDAC: didecyl dimethyl ammonium chloride

\begin{tabular}{|c|c|}
\hline Purpose & $\begin{array}{l}\text { Disinfectant and recommended concentration } \\
\text { (double minimum effective concentration in most cases) }\end{array}$ \\
\hline \multicolumn{2}{|l|}{ Field use } \\
\hline $\begin{array}{l}\text { Nets, boots, other } \\
\text { equipment }\end{array}$ & $\begin{array}{l}\text { TriGene Viricidal Surface Disinfectant Cleaner }\left(0.2 \mathrm{ml}^{-1}\right) \\
\text { F10 Super Concentrate Disinfectant }\left(0.7 \mathrm{ml} \mathrm{l}^{-1}\right) \\
\text { DDAC }\left(2 \mathrm{ml} \mathrm{l}^{-1}\right) \\
4 \% \text { bleach }\left(1.8 \mathrm{~g} \mathrm{l}^{-1} \text { sodium hypochlorite }\right)\end{array}$ \\
\hline $\begin{array}{l}\text { Instruments (scales, } \\
\text { scissors, calipers) }\end{array}$ & $70 \%$ ethanol $\left(700 \mathrm{ml} \mathrm{l}^{-1}\right)$ wipes or liquid \\
\hline \multicolumn{2}{|l|}{ Laboratory use } \\
\hline $\begin{array}{l}\text { Cultures, disposable } \\
\text { equipment }\end{array}$ & $\begin{array}{l}70 \% \text { ethanol }\left(700 \mathrm{ml} \mathrm{l}^{-1}\right) \\
\text { Virkon }\left(2 \mathrm{~g} \mathrm{l}^{-1}\right) \\
\text { TriGene Viricidal Surface Disinfectant Cleaner }\left(0.2 \mathrm{ml} \mathrm{l}^{-1}\right) \\
\text { F10 Super Concentrate Disinfectant }\left(0.7 \mathrm{ml} \mathrm{l}^{-1}\right) \\
\text { DDAC }\left(2 \mathrm{ml} \mathrm{l}^{-1}\right) \\
4 \% \text { bleach }\left(1.8 \mathrm{~g} \mathrm{l}^{-1} \text { sodium hypochlorite }\right)\end{array}$ \\
\hline Amphibian carcasses & $\begin{array}{l}\text { Heat }\left(60^{\circ} \mathrm{C} \text { for } 30 \mathrm{~min}\right) \\
70 \% \text { ethanol }\left(700 \mathrm{ml} \mathrm{l}^{-1}\right)\end{array}$ \\
\hline \multicolumn{2}{|l|}{ Captive husbandry } \\
\hline $\begin{array}{l}\text { General cleaning and } \\
\text { sterilising inanimate } \\
\text { tanks and enclosures }\end{array}$ & $\begin{array}{l}\text { TriGene Viricidal Surface Disinfectant Cleaner }\left(0.2 \mathrm{ml}^{-1}\right) \\
\text { F10 Super Concentrate Disinfectant }\left(0.7 \mathrm{ml} \mathrm{l}^{-1}\right) \\
4 \% \text { bleach }\left(1.8 \mathrm{~g} \mathrm{l}^{-1} \text { sodium hypochlorite }\right) \\
\text { Virkon }\left(2 \mathrm{~g} \mathrm{l}^{-1}\right) \\
\text { Heat }\left(60^{\circ} \mathrm{C} \text { for } 30 \mathrm{~min}\right)\end{array}$ \\
\hline
\end{tabular}

field than those that are effective in vitro. In Table 2 the recommended concentrations of the 3 disinfectants tested here, as well as Virkon (Antec International) and DDAC are twice the minimum effective concentrations for an exposure of $1 \mathrm{~min}$. It is also recommended that equipment be cleaned prior to disinfection. According to the Material Safety Data Sheets of the manufacturers, F10 and TriGene are non-toxic, non-irritant, noncorrosive and biodegradable ${ }^{\mathbf{1}} \underline{\underline{2}}$ (ChemWatch 2006). In contrast, bleach (sodium hypochlorite), a commonly used disinfectant, is considered a dangerous and hazardous chemical (ChemWatch 2006). Bleach is also toxic to aquatic organisms and may cause long-term damage to aquatic environments (ChemWatch 2006). In previous studies, DDAC was determined to be highly effective at low concentrations $\left(1 \mathrm{ml} \mathrm{l}^{-1}\right)$ (Johnson et al. 2003). Since DDAC can be toxic to aquatic invertebrates and fish at concentrations of 1 ppm (Farrell et al. 1998), care is needed to avoid local contamination of water bodies when used in the field. TriGene and F10 are also effective at concentrations of $<1 \mathrm{ml} \mathrm{l}^{-1}$. Smaller volumes of these concentrates would need to be taken into the field, saving space, expense and reducing the risk of release into the environment.

A range of strategies is now available to be used in different situations, particularly for field work, laboratory research, captive husbandry and for instruments used repeatedly on frogs (Table 2). In conclusion, TriGene and F10 are preferable for use in the field over the previously recommended DDAC products, as the former are active at much lower concentrations and appear to have no record of environmental toxicity. Any of these 3 disinfectants is recommended instead of bleach due to their efficacy at lower concentrations and less hazardous qualities. Research on the efficacy of disinfectants in the field would complete the results from the laboratory studies. However, evaluating the viability of Batrachochytrium dendrobatidis in natural samples cannot currently be done owing to overgrowth by other saprophytic fungi and bacteria that out compete $B$. dendrobatidis in culture media (Johnson \& Speare 2005).

F10 has been used to treat fungal infections in reptiles and birds ${ }^{\mathbf{1}}$, but there does not appear to be data on its safety for amphibians. The zoosporangia of Batrachochytrium dendro- 
batidis in infected frogs are intracellular, surrounded by modified intracellular structures, possibly explaining why a fungus so sensitive to antifungal agents in vitro is so difficult to cure in vivo (Berger et al. 2005a). Research into the safety and efficacy of F10 as a potential treatment for chytridiomycosis of amphibians is needed.

Acknowledgements. This study was funded by the Department of Environment and Heritage (Australia) tender 16/2004. F10 was donated by Essential Chemicals. The authors have no commercial conflicts of interest and no connections to the manufacturers of any of the disinfectants discussed in this paper.

\section{LITERATURE CITED}

Anonymous (1998) Betadine povidone-iodine product monograph, 4th edn. Faulding \& Co., Ltd. (Available on request: www.faulding.com.au/)

Australian Government Department of Environment and Heritage (2006) Threat abatement plan: infection of amphibians with chytrid fungus resulting in chytridiomycosis. Department of Environment and Heritage, Canberra

Berger L, Speare R, Daszak P, Green DE and 10 others (1998) Chytridiomycosis causes amphibian mortality associated with population declines in the rain forests of Australia and Central America. Proc Natl Acad Sci USA 95: 9031-9036

Berger L, Hyatt AD, Speare R, Longcore JE (2005a) Life cycle stages of the amphibian chytrid Batrachochytrium dendrobatidis. Dis Aquat Org 68:51-63

Berger L, Marantelli G, Skerratt LF, Speare R (2005b) Virulence of the amphibian chytrid fungus Batrachochytrium dendrobatidis varies with the strain. Dis Aquat Org 68:47-50

Bonaccorso E, Guayasamin JM, Mendez D, Speare R (2003) Chytridiomycosis as a possible cause of population declines in Atelopus cruciger (Anura: Bufonidae). Herpetol Rev 34: 331-334

Editorial responsibility: Alex Hyatt, Geelong, Victoria, Australia
Bosch J, Martínez-Solano I, García-París M (2001) Evidence of a chytrid fungus infection involved in the decline of the common midwife toad (Alytes obstetricans) in protected areas of central Spain. Biol Conserv 97:331-337

Burrowes PA, Joglar RL, Green DE (2004) Potential causes for amphibian declines in Puerto Rico. Herpetologica 60: 141-154

ChemWatch (2006) Chemgold CD 2006/1. ChemWatch, Melbourne

Farrell AP, Kennedy CJ, Wood A, Johnston BD, Bennett WR (1998) Acute toxicity of a didecyldimethlyammonium chloride-based wood preservative, Bardac 2280, to aquatic species. Environ Toxicol Chem 17:1552-1557

Fellers GM, Green DE, Longcore JE (2001) Oral chytridiomycosis in the mountain yellow-legged frog (Rana muscosa). Copeia 4:945-953

Johnson M, Speare R (2005) Possible modes of dissemination of the amphibian chytrid Batrachochytrium dendrobatidis in the environment. Dis Aquat Org 65:181-186

Johnson M, Berger L, Philips L, Speare R (2003) Fungicidal effects of chemical disinfectants, UV light, desiccation and heat on the amphibian chytrid, Batrachochytrium dendrobatidis. Dis Aquat Org 57:255-260

Lips KR, Brem F, Brenes R, Reeve JD and 6 others (2006) Emerging infectious disease and the loss of biodiversity in a neotropical amphibian community. Proc Natl Acad Sci USA 102:3165-3170

Mutschmann F, Berger L, Zwart P, Gaedicke C (2000) Chytridiomycosis on amphibians - first report from Europe. Berl Muench Tieraerztl Wochenschr 113:380-383

Puschendorf R, Castañeda F, McCranie JR (2006) Chytridiomycosis in wild frogs from Pico Bonito National Park, Honduras. EcoHealth 3:178-181

Waldman B, van de Wolfshaar KE, Klena JD, Andjic V, Bishop $\mathrm{P}$, Norman RJ de B (2001) Chytridiomycosis in New Zealand frogs. Surveillance 28(3):9-11

Wilson J, Margolin AB (2003) Efficacy of glutaraldehyde disinfectant against Cryptosporidium parvum in the presence of various organic soils. AOAC Int J 86:96-100

Submitted: September 29, 2006; Accepted: November 27, 2006 Proofs received from author(s): January 29, 2007 